2018, volume 7, issue 3

Okpala, O.P., \& Iredele, O.O. (2018). Corporate Social and Environmental Disclosures and Market Value of Listed Firms in Nigeria. Copernican Journal of Finance \& Accounting, 7(3), 9-28. http:// dx.doi.org/10.12775/CJFA.2018.013

\author{
Okwy Peter Okpala* \\ University of Lagos \\ Oluwamayowa Olalekan Iredele** \\ University of Lagos
}

\title{
CORPORATE SOCIAL AND ENVIRONMENTAL DISCLOSURES AND MARKET VALUE OF LISTED FIRMS IN NIGERIA
}

Keywords: Social and Environmental Disclosures, Market Value, Nigeria.

J E L Classification: M40, Q01, Q2, Q4, Q25.

\begin{abstract}
This study examines the effect of corporate social environmental disclosure (CSED) on the market value of eighty-four (84) listed firms in Nigeria, which were purposively selected from the period 2011 to 2016. The aggregate of (CSED) were regressed on Market Value (Tobin's Q), while Firm size, financial performance, board size, leverage, affiliation to foreign company and industry type were factored in as extraneous variables. Data were obtained through content analysis of annual reports of sampled firms and were analysed through descriptive statistics and regression analysis. The result of the descriptive analysis showed that the mean score for the CSED is above average and the standard deviation for almost all the variables is low which indicated that the deviation of the actual data from their mean is not significant. The OLS result revealed that CSED, firm size, financial performance, affiliation with foreign company
\end{abstract}

Date of submission: January 9, 2019; date of acceptance: February 8, 2019.

* Contact information: okwyokpalap@yahoo.com, Department of Accounting, University of Lagos, Akoka, Nigeria 100213, phone: +234 8033060763; ORCID ID: https:// orcid.org/0000-0002-9943-6730.

** Contact information: miredele@yahoo.com, Department of Accounting, University of Lagos, Akoka, Nigeria 100213, phone: +234 8037076057; ORCID ID: https://orcid. org/0000-0002-1661-9460. 
and industry type have significant effect on the market value of firms, while Board size and leverage do not significantly influence the market value of firms. The study recommends that firms should disclose information on their environmental performance as a way of adding value.

\section{INTRODUCTION}

Contemporary business organizations operate in a society that expects them not only to fulfil economic functions by producing goods and services, but also to take on social and environmental roles and responsibilities (Panwar \& Hansen, 2009). This practice is not a recent phenomena, it first started to emerge as a substantial discipline in the early 1970s (Gray \& Bebbington, 2001; Owen, 2008). It has witnessed a remarkable growth more because of the increasing global profile of environmental issues. Firms can no longer ignore the social problems of the society or the destructive impacts of their activities on the environment (Akinlo \& Iredele, 2014). There is the demand to provide greater accountability of social and environmental information through various means of corporate communication aimed at informing a wide range of audiences. Several global and national institutions like United Nation's Protocols and Agreements on Environment, Global Reporting Initiatives (GRI) and National Environmental Standards and Regulatory Enforcement Agency (Nigeria) have been created with the objectives of enunciating varying norms of interaction with environment, proposing standards for engaging stakeholders and developing frameworks for reporting on socially and environmentally impactful activities of organisations. These institutions, in concert with several social and environmental advocacy groups provide moral and legal foundation for social and environmental disclosures (Enahoro, 2009).

Within the past decade there has been a considerable increase in the number of companies that have responded to this challenge by presenting information on their social and environmental activities. In the KPMG's international survey of Corporate Social Responsibility (CSR) reporting covering 34 countries, a notable increase was observed in the number of companies presenting CSR reports from 50\% in 2005, to 80\% in 2008 and 95\% in 2011 (KPMG, 2011). The survey shows that countries are getting better at reporting the environmental and social trends and risks affecting their businesses. Emerging economies of India, Indonesia, Malaysia and South Africa have the highest Corporate Responsibility (CR) reporting rates in the world (KPMG, 2015). Unlike in the 
2011 survey, when only $20 \%$ of the companies included CSR data in their annual report, almost 60\% include CSR data in annual financial reports by 2015. Thus, including CSR data in annual financial report is now a firmly established global trend. It is predicted that non-financial reporting will soon become a required business practice and companies will need to focus on how best to integrate their financial and non-financial information (KPMG, 2015). Already integrated reports are required by regulation and/or law in South Africa and India. Although only $11 \%$ of companies surveyed by KPMG in 2015 have integrated reports, over $50 \%$ included CSR information in annual report, with many moving toward convergence of CSR and annual reports.

Despite the increasing level of interest in corporate social environmental disclosure [hereafter called CSED], it is not yet clear whether the market assigns real value to it. Establishing the influence of the CSED on the market value of firm will provide further rational basis for disclosure or non-disclosure of this iinformation, besides responding to stakeholder pressure. The motivational basis for engaging in CSED can be altruistic or economic (Uwuigbe, Uwuigbe \& Ajayi, 2011). Scientific evidence and consumer reactions suggest that firms are likely to be rewarded for higher level CSED. This reward is expected to manifest in the market value of the firm (Akinlo \& Iredele, 2014). Dasgupta, Laplante and Mamingi (1998) assert that capital markets respond to information on environmental performance and reacts negatively to news of adverse environmental incidents and positively on such disclosures such as use of cleaner technologies. Natali, Lars, Hasseli and Henrik (2009); Laabs (2012) and Li, Gong, Zhang and Koh (2017) affirmed that CSED has value relevance as it is expected to affect future earnings of the firm. In the light of this on-going debate on the association between CSED and market value of firms, this study attempts to extend academic literature on this debate within the context of developing country like Nigeria. The objective of the study is to determine the effect of disclosure of social and environmental issues on the market value of listed firms in Nigeria.

The rest of this paper provides a brief review of literature and hypothesis development. This is followed by a discussion of the methodology and then the data analysis. The final section provides the discussion and conclusion of the study. 


\section{LITERATURE REVIEW AND HYPOTHESIS DEVELOPMENT}

\section{Social and Environmental Disclosure (SED)}

Corporate social and environmental disclosure (CSED), which is also known as corporate social responsibility reporting (CSR) (Deegan, 2007), entails the practice whereby firms willingly accommodate social and environmental issues in their business values and operations and report same (Mohammed \& Abubakar, 2014). These CSED are important tools for decision making (Shil \& Paramanik, 2009). CSED has been extensively addressed in literature especially in developed countries, in many of these countries, it is being widely accepted as one of the ways in which businesses can take responsibility for the effects for their social and environmental activity and account for it through the provision of information.

Researchers have used various means to measure the dimensions of CSR. Some have used content analysis of firms' disclosure documents (Abbott \& Monsen, 1979; Webb, Cohen, Nath \& Wood, 2009), others have used experiments and case studies (O'Dwyer, 2011). These methods, however, often suffer from lack of generalizability and are influenced by participant biases. In order to overcome this, CSR are measured uniformly and consistently across a wide range of companies (Malik, 2014). Other studies therefore operationalizes CSED through a number of measurable variables, which can be used in testing the CSED/firm market value relationship. Specifically, Ngwakwe (2009) identified three broad classes of measurable variables; employee health and safety (EHS), waste management (WM) and Community development (CD). Other measurable variables under the scope of CSED include employee welfare and social benefit (EWSB), and donation and charitable contributions (DCC). Oba (2012), investigated whether three corporate social responsibility (CRS) variables - community social responsibility (CCRS), human resource management (HRM) and charitable contribution (CC).

In line with GRI performance indicators, (Akinlo \& Iredele, 2014) measured corporate environmental disclosure using environmental pollution and control policy (EPC), energy policy (ENP), impact on biodiversity (BIO), waste management Cost (WSM), award received for installing environmental management system (AWR), environmental research and development cost (ERD) and cost of compliance with environmental laws (CEL). Similarly, Measurements of variables for the study were based on the global reporting initiative (GRI 
3.1) framework. Six variables, consistent with GRI framework, are identified as a consistent measure of CSED. These are: (i) Environmental Protection (ii) Energy Conservation (iii) Community Development (iv) Employee Welfare (v) Product Responsibility (vi) Human Rights and Protection of Stakeholders Interest.

\section{Frameworks for corporate social and environmental disclosure}

Among the list of framework for reporting social and environmental issues, the global reporting initiative (GRI) guideline is the most definitive, widely-accepted and commonly- applied framework for environmental reporting globally (Hindley \& Buys, 2012). The Global Reporting Initiative (GRI) is a non-profit organisation that promotes economic, environmental and social sustainability and provides all companies and organisations with a comprehensive sustainability reporting framework that is widely used around the world. The first version of the Guidelines, G1 was launched in year 2000. Subsequently, others followed; G2 (2002); G3 (2006), with updated and complete version (G3.1) in 2011. The G4 was launched in 2013, though will soon be finally replaced by GRIS standards, this study is based on the G3.1 because it is the applicable guideline for the period being covered in this study.

\section{CSED and Market Value of Firms}

Current debate on how environmental disclosure impacts the market value of firms is basically divided into two schools namely; the cost concerned school and the value creation school. The cost-concerned school argues that environmental investments and high environmental disclosure represent only increased costs, resulting in decreased earnings and lower market value. Consequently, the relationship between environmental disclosure and market value is expected to be negative (Lars, Henrik \& Siv, 2005). Value creation school regards environmental efforts as a way of increasing competitive advantage and improve financial returns to the investors, the relationship between environmental disclosure and market value in this regard is expected to be positive (Konar \& Cohen, 2001; Akinlo \& Iredele, 2014).

One particular development that helps CSED's influence on market value of a firm is the activities of the ethical investors. Ethical investors are people who deliberately look for and use investment vehicles that reflect their values 
and concerns regarding conduct of business activities (Williams, 1999). These investment vehicles (ethical investments) select companies for investments, based on consideration for social and environmental performance, besides economic performance. Hence, they are also referred to as social responsibility investments. The investors are guided, not just by profit maximisation motive, but also by moral duty to maximise stakeholder's welfare (Etzioni, 1988). Cassidy (2003) posits that substitution of long-term sustainability for short term volatility and risk is needed in contemporary business. Economic, social and environmental performance are often linked with adequate disclosures. Chami, Cosimano and Fullenkamp (2002) argue that ethical reputation is the valuable intangible asset which will affect market price of shares. With the steady increase in the number of ethical investors and volume of funds for ethical investments, demand for shares of companies with good quality CSED would increase thus driving up their prices.

\section{Theoretical framework}

Several theoretical perspectives have already established the notion that organizations need to engage in CSR activities and report such activities. The theoretical perspectives upon which CSR is based and which also provide the theoretical foundation for analyzing the issue of CSED include such theories as the legitimacy theory, stakeholder theory and the resource based view theory. While legitimacy theory argues that organizations seek to ensure that they operate within the bounds and norms of society (Gray, Kouhy \& Lavers, 1995). It entails conformity of an organization with the value of the society within which it functions (Deegan, 2002). The stakeholder theory asserts that corporation's continued existence requires the support of the stakeholders and their approval must be sought and the activities of the corporation adjusted to gain that approval (Chan, 1996). However, this study is hinged on the resource based theory. Resource based theory presumes that firms are bundles of heterogeneous resources and capabilities which are imperfectly mobile across firms and for certain types of firms these capability or resource can lead to a sustained competitive advantage for the firm (Barney, 1991; Hart, 1995). The implication of this theory is that CSED can be used as a strategic tool for corporate differentiation and also as a basis to develop predictive patterns of CSR investment for specific firms. This theory suggests the use of CSED as strategy for differentiation, beyond just looking for legitimacy or pleasing stakeholders. In other 
words, Resource Based View (RBV) can be used to explain why the extent and level of CSED can influence the market value of the firm.

\section{Prior empirical studies}

The preponderance of the literature on CSED examined the relationship between the phenomenon and financial performance, while some examined the influence of CSED on market value of firm. Rockness, Schlachter and Rockness (1986) conducted a research on hazardous waste disposal in the chemical industry (environmental performance) and the return on equity as a measure of financial performance. In their study they found positive relations; companies with higher financial performance are those who have smaller amounts of chemical waste disposal. Wang, Sewon and Claiborne (2008), from Chinese perspective indicated that firm performance, measured by return on equity, is positively related to voluntary disclosures. Furthermore, Hossain and Hammani (2009) in a study using listed Qatari companies found profit insignificant in explaining the degree of social and environmental disclosures. Andrikopoulos \& Kriklani (2012) using reported practices of environment disclosure on the websites of companies listed in Copenhagen (Denmark) Stock Exchange found that profitability are significantly associated with the degree of environmental disclosure. This is contrary to the conclusions of Akbas (2014) which asserts that profitability is negatively related quantitative information disclosure, based on analysis of data from Turkey.

Several researchers other studies have associated social and environmental disclosures with the value of the firm. For instance, a study by Konar and Cohen (2001) related the market value of firms in the S\&P 500 to objective measures of environmental performance. The study found that bad environmental performance is negatively correlated to the value of intangible assets of the firm. This implies that good environmental performance and reporting improve firm valuation. Funk (2003) posits that companies that actively manage a wide range of sustainability indicators are better able to create long-term value for all stakeholders. Further, Lo and Sheu (2007) examined whether corporate sustainability has an impact on market value, using large United States' non-financial firms. Using Tobins $q$ as proxy for firm value, they found a significant positive relation between corporate sustainability and the market value of the firm. Using data collected in Egypt, Wahba (2008) corroborated the finding that social responsibility reporting exerts positive and significant im- 
pact on firm market value. Furthermore, Plumlee, Brown, Hayes and Marshall (2010) investigate the relationship between the quality of a firm's voluntary environmental disclosures and firm value by exploring the relationships between components of firm value and voluntary environmental disclosure quality. The study concludes that increased voluntary environmental disclosure quality is associated with firm value. Further, the result from a study conducted by Schadewitz and Niskala (2010) found that communication of social and environmental performance is an important explanatory factor for firm's value. Specifically, the result indicates that GRI responsibility reporting is part of a firm's communication tools for the purpose of reducing information asymmetry between managers and investors, thus helping to produce a more precise market valuation of a firm.

However, a study by Carnevale, Mazzuca and Venturini (2011) which applied value-relevance analysis to a sample of one hundred and thirty (130) listed European banks, provided mixed result in the cross-country analysis: in some countries, social reports are value relevant while in others it negatively affects the stock price. In a recent study, Qiu, Shaukat and Tharyan (2016) examined the link between firm's social and environmental disclosures and its profitability and market value. The study did not find any relationship between environmental disclosure and profitability. Interestingly, firms that make higher social disclosures have higher values. Hence, the study suggests that it is the social disclosures that matter to the investors, not the environmental disclosures.

Limited number studies have been conducted in this regard in the Nigerian perspective. Adeyemi and Ayanlola (2015) opine that voluntary CSR disclosure in Nigeria is haphazard and need to be regulated. Oba, Fodio and Soje (2012) investigated the relationship between disclosure of environmental information and profitability measured by return on capital employed (ROCE). The results confirmed a positive relationship. This is corroborated by a study by Duke and Kankpang (2013) which also established a significant positive association between social responsibility and ROCE (as proxy for performance) of Nigerian firms. Uwuigwe, Uwuigwe and Ajayi (2011) investigated environmental visibility and corporate social disclosures among listed companies in Nigeria. From the findings, they concluded that environmentally sensitive companies disclose more environmental information in their annual report. Further, Appah (2011) analysed data collected between 2005 and 2007 from annual reports of Nigerian listed companies and found support for the assertion that environmentally sensitive disclose more social and environmental information 
than non-environmentally sensitive companies. Not many studies in Nigeria have examined the relationship between firm value and social and environmental disclosures. Akinlo and Iredele (2014) established significant positive relationship between corporate environmental disclosures and market value, measured by Tobins q ratio. It appears that there is dearth of study on the influence of social and environmental disclosure on market value of Nigerian listed firms. It is needful to investigate this relationship in a developing country like Nigeria to provide empirical evidence on the need for firms to be environmentally responsible. It is on this basis that we we hypothesize that:

$\mathrm{H}_{0} 1$ : CSED has no significant effect on the market value of firms in Nigeria.

\section{THE RESEARCH METHODOLOGY AND THE COURSE OF THE RESEARCH PROCESS}

\section{The sample and data}

The population for the study consist of 180 companies listed on the Nigerian Stock Exchange as at 31st December 2016. Adopting purposive sampling based on the impact of companies' activities on the environment, data were gathered from a sample comprising 504 firm-year observations of 84 listed companies over the period 2011-2016. This was after due screening, to eliminate companies that have been delisted and those with incomplete annual reports for the sample period. Data obtained were analysed using descriptive statistics and inferential statistics.

\section{Measurement of variables}

Measurements of variables for the study were based on the global reporting initiative (GRI) framework. Six variables, consistent with GRI framework, are identified as a consistent measure of SED. These are: (i) Environmental Protection (ii) Energy Conservation (iii) Community Development (iv) Employee Welfare (v) Product Responsibility (vi) Human Rights and Protection of Stakeholders Interest. A kinder Lydenberg Domini (KLD) social environmental performance rating system was used to measure the SED scores (RS). A score of ' 1 'was assigned if item is reported and ' 0 ' if it is not reported as follows: 


$$
R S=\sum_{I=1}^{6} r_{1}
$$

where:

RS $=$ Reporting Score

$\mathrm{r}_{1}=$ A score of (1) if the item is reported and (0) if not reported.

$\mathrm{I}=1,2 \ldots 6$.

A firm could score a maximum of (6) points and a minimum of (0) under forty (40) SED parameters and checklists identified and divided into six main categories. Measurement of market value and other variables are listed in appendix 1 .

\section{Model specification}

The models for the study determine the relationship between CSED and Market value of the firm. A linear regressing model is used to express the effect of a dependent (explained) variable and several independent (explanatory) variables. The general form of panel regression equation as stated in Field (2005) and Asteriou and Hall (2007) is:

$$
y_{i, t}=\beta_{0}+\beta_{1} x_{1 i, t}+\beta_{2} x_{2 i, t}+\ldots+\beta_{k} x_{k i, t}+u_{i, t}
$$

Where $y_{i, t}$ is the variable to be forecast and $x_{1 i, t} \ldots x_{k i, t}$ are the k predictor variables. Each of the predictor variables must be numerical. The coefficients $\beta, \ldots \beta_{k}$ measures the effect of each predictor after taking account of the effect of all other predictors in the model. Thus, the coefficients measure the marginal effects of the predictor variables. In order to predict the relationship between social and environmental disclosures and market value, CSED is added as a predictor of Market Value to the predictors listed in equation 2:

$$
M V=\beta_{o}+\beta_{1} C S E D+\beta_{2} S I Z+\beta_{3} R O E+\beta_{4} B S+\beta_{5} L E V+\beta_{6} A F F L .+\beta_{7} I N D+\mu_{3}
$$


Where, MV is the Market value, CSED is the corporate social and environment disclosure, Size represents firm size, ROE represent firm's financial performance, LEV represent a firm's leverage, Affl represents affiliation to foreign company, Ind represents industry. The inclusion of control variables is informed by earlier related studies (Mathuva, Barako \& Wachira, 2017; Barth, Cahan, Chen \& Venter, 2016). Further definitions of all the variables are presented in appendix 1.

\section{ANALYSIS AND RESULTS}

Table 1. Descriptive statistics

\begin{tabular}{|l|c|c|c|c|c|c|c|c|}
\hline \hline & SED & BS & FINPER & LEV & SIZE & AFFL & IND & MV \\
\hline \hline Mean & 4.123016 & 10.75595 & 0.203343 & 2.575451 & 10.67471 & 0.511905 & 0.632937 & 4.273533 \\
\hline Median & 4.000000 & 9.000000 & 0.091476 & 1.496971 & 10.45970 & 1.000000 & 1.000000 & 0.362103 \\
\hline Maximum & 6.000000 & 23.00000 & 3.304091 & 75.71508 & 12.66076 & 1.000000 & 1.000000 & 125.2040 \\
\hline Minimum & 2.000000 & 5.000000 & -0.384206 & 0.001835 & 9.090022 & 0.000000 & 0.000000 & 0.000698 \\
\hline Std. Dev. & 0.983333 & 3.915860 & 0.341206 & 4.453170 & 0.977231 & 0.500355 & 0.482483 & 13.05492 \\
\hline Skewness & -0.109740 & 1.067821 & 4.216591 & 10.54315 & 0.502312 & -0.047633 & -0.551599 & 4.841383 \\
\hline Kurtosis & 2.572688 & 3.415750 & 28.05471 & 157.4260 & 2.140723 & 1.002269 & 1.304262 & 30.47467 \\
\hline Jarque-Bera & 4.846104 & 99.41004 & 14676.00 & 510132.5 & 36.70018 & 84.00011 & 85.94408 & 17820.88 \\
\hline Probability & 0.088651 & 0.000000 & 0.000000 & 0.000000 & 0.000000 & 0.000000 & 0.000000 & 0.000000 \\
\hline Sum & 2078.000 & 5421.000 & 102.4849 & 1298.027 & 5380.054 & 258.0000 & 319.0000 & 2153.860 \\
\hline Sum Sq. Dev. & 486.3730 & 7712.982 & 58.55998 & 9974.855 & 480.3549 & 125.9286 & 117.0933 & 85726.80 \\
\hline Observations & 504 & 504 & 504 & 504 & 504 & 504 & 504 & 504 \\
\hline \hline
\end{tabular}

S o u r c e : author's computation, using E-view 8, 2017.

The result in table 1 shows the mean CSED of 4.12, out of maximum 6. This signifies an above average level of disclosure. Also, it shows that all the series display a high level of consistency being that their mean and median values are within the maximum and minimum values of the series. Also the deviation of the actual data from their mean value are very low, this is indicated by the relatively low value of the standard deviations. 


\section{Effect of SED on Firms' Market Value}

The regression model in equation 2 was used to determine the effect of SED practices on firms' market value. SED, SIZ, FinPer, BS, LEV, Affl and Ind are the independent variables, and MV is the dependent variable. Prior to the regression estimation, a stationary test was conducted to ascertain the reliability of the data for running the OLS. This was done using Augmented Dickey-Fuller (ADF) Techniques for unit roots at $5 \%$ as shown in table 2 .

Table 2. Stationary test of variables in the firms

\begin{tabular}{|c|c|c|c|l|}
\hline \hline Variables & Statistic & Stationary & Probability & \multicolumn{1}{|c|}{ Remarks } \\
\hline \hline MV & 357.312 & $1(0)$ & 0.0000 & Stationary at levels \\
\hline SED & 43.4485 & $1(2)$ & 0.0000 & Stationary at Second Difference \\
\hline Size & 510.196 & $1(1)$ & 0.0000 & Stationary at First Difference \\
\hline Roe & 359.915 & $1(0)$ & 0.0000 & Stationary at levels \\
\hline BS & 379.142 & $1(1)$ & 0.0000 & Stationary at First Difference \\
\hline Lev & 268.775 & $1(0)$ & 0.0000 & Stationary at levels \\
\hline Affl & 83.7919 & $1(0)$ & 0.0003 & Stationary at levels \\
\hline Ind & 33.5037 & $1(0)$ & 0.0063 & Stationary at levels \\
\hline \hline
\end{tabular}

** Probabilities are computed assuming asymptotic normality.

S o u r c e : authors' computation (2017) with E-View 9.0.

The result shows MV, FINPER, LEV, AFFL, IND are stationery at level form while SIZE and BS are integrated at order (1). SED is the only variable integrated at order (2). Hence it may be concluded that there is no long run relationship among market value (MV), social and environmental disclosures (SED), size, financial performance (ROE), board size (BS), leverage (Lev), Affiliation (Affl) and industry grouping (Ind). The result of the OLS to test the cause-effect relationship between Market Value (dependent variable) and the independent variables (SED, SIZE, BS, ROE, LEV, AFFL, IND) is presented in table 3. 
Table 3. Regression result of MV and other variables

\begin{tabular}{|l|c|c|c|c|}
\hline \hline \multicolumn{1}{|c|}{ Variable } & $\begin{array}{c}\text { Estimated } \\
\text { Coeffficient }\end{array}$ & Standard Error & t-value & Sig \\
\hline \hline Constant term & 25.71398 & 7.517940 & 3.420350 & 0.0007 \\
\hline D (SED) & -1.685253 & 0.605650 & -2.782553 & 0.0056 \\
\hline D log (Siz) & -0.776899 & 0.333598 & -2.328846 & 0.0203 \\
\hline (Affl) & 3.884138 & 1.300466 & 2.986729 & 0.0030 \\
\hline D (BS) & -0.079699 & 0.169114 & -0.471271 & 0.6377 \\
\hline Roe & 5.468209 & 1.724659 & 3.170602 & 0.5682 \\
\hline Lev & -0.76335 & 0.133654 & -0.571137 & 0.0015 \\
\hline Ind & 4.040236 & 1.268707 & 3.184530 & \\
\hline R2 & 0.091089 & & & \\
\hline Adjusted R2 & 0.078261 & & & \\
\hline F- Statistic & 7.101111 & & & \\
\hline Prob (F- Statistic) & 0.00000 & & & \\
\hline Durbin Watsin & 0.24040 & & & \\
\hline \hline
\end{tabular}

Pr e d i c t o r : (Constant), D (SED), D log (Siz), Affl, D (BS), FinPer, Lev, Ind.

Dependent Variable:MV.

S o u r c e : authors' computation (2017) with E-View 9.0.

The result in table 3 is the regression results of SED, SIZ, Affil, BS, ROE, BS, LEV and Ind on MV. The table indicates that the regression model is significant ( $\mathrm{p}<0.05, \mathrm{~F}=7.10111$ ) and has an adjusted $\mathrm{R}^{2}$ is $7.82 \%$. The results particularly indicate that CSED has a significant negative effect on market value $(\beta=-1.6852 ; t=-2.7825 ; p<0.05)$. Thus, we reject the hypothesis of the study. We therefore conclude that CSED has a significant effect on the market value of listed firms in Nigeria. The direction of the relationship is negative, which implies that for each unit increase in SED practice, MV decreases by 1.6852. This is contrary to the result of previous studies in Nigeria (see Jaggi \& Freedman, 1992; Walley \& Whitehead, 1994; Lars, Henrik \& Siv, 2005).

The results of the explanatory variables show that Affl $(\beta=3.8841$; $\mathrm{t}=2.9867 ; \mathrm{p}<0.10), \operatorname{ROE}(\beta=5.4682 ; \mathrm{t}=3.1706 ; \mathrm{p}<0.10)$ and Ind $(\beta=4.0402$; $\mathrm{t}=3.1845 ; \mathrm{p}<0.10$ ) have a significant positive effect on the market value of list- 
ed firms. By implication, being a subsidiary of foreign parent company, significantly influences the market value in a positive way. Similar result was found in Hyang, Wonsik and Sang (2012). Also, firms with better financial performance have higher market value. This is because profitability or financial performance is expected to impact on the value of shares as the benefits of profitability would be priced in by the market. The result supports the extant literature (Baye, 2006; Michaely \& Roberts, 2007; Shin-Ping \& Hui-Ju, 2011) which found strong positive link between financial performance and market value of firms. Similarly, the industry a firm belongs to reasonably affect its market value.

SIZE $(\beta=-0.7768 ; t=-2.3288 ; p>0.10), B S(\beta=-0.0796 ; t=-0.471271$; $\mathrm{p}>0.10)$, and LEV $(\beta=-0.7633 ; \mathrm{t}=-0.5711 ; \mathrm{p}>0.10)$ have a non-significant negative effect on MV with the exception of SIZE which have a significant effect. The result for SIZE corroborates extant literature which found size to be negatively related to firm value (Morck, Shleifer \& Vashny, 1988; McConnell \& Servaes, 1990). Also, the result of this study supports the findings in Kamangue \& Ngugi (2013) that higher expenses and poor communication in larger boards make smaller boards preferable for value creation. Nevertheless, Taufik, Widyastuti and Yam (2017) opines that corporate governance, which is better achieved with larger board, is important for improving firm value. Modigliani and Miller (1958) argue that leverage does not affect firm value which aligns with the result of this study.

\section{DISCUSSION AND CONCLUSION}

Unexpectedly, the result of this study shows a significant negative relationship between social and environmental disclosures and the market value of firms in Nigeria. This does not support our a priori expectations of a positive relationship between social and environmental disclosures and market value. Our prior expectation was based on the resource based view which sees capabilities such as reputation for environmental performance as valuable intangible assets and therefore value-relevant. The thinking behind this theory is that beyond being a legitimizing tool, CSED can be used as strategy for differentiation which could lead to sustained competitive advantage. This result, instead, mildly supports another strand of extant literature such as Walley and Whitehead (1994), Turnbull (1997), Lars, Henrik and Siv (2005) and the 'the cost concern' school of thought, which see CSED investments as representing increased 
costs and therefore will have negative influence on the market value of firms. The reason for this result may not be unconnected to the near absence of ethical investors in Nigeria, compared to advanced economies. At the moment, capital market participants do not regard environmental performance as important, so far they can ascertain the financial viability of the company.

The result also revealed a positive association between market value and affiliation status. This indicates that the country of origin of a firm has value creating effect. We also found that financial performance can be a major determinant of firm value. This is because financial performance increases the shareholders' wealth and the value of the company's assets. It has been argued that firm value must be the estimates of future profits. This is corroborated by Baye (2006) who holds that maximizing profit is maximising firm value. It is therefore not expected that firms that report losses from one year to another be regarded by investors as firms with high value. From the result of this study, there is also claim that industry classification has a value-adding effect to the firm. We provide evidence that that firm value decreases with the size of the company. The possible explanation for this is that it is more likely that smaller firms focus on better environmental practices in order to gain reputations and add value, of which less attention is given to this by bigger firms which have more issues to contend with. Some previous literatures corroborates this finding (Morck, Shleifer \& Vashny, 1988; McConnell \& Servaes, 1990; Smith \& Watts, 1992). Lack of flexibility, tardiness in decision making, lack of personal touch in customer service may be responsible for results in these studies.

In conclusion, though the effect of CSED and market value of firms in Nigeria is not significant at the moment, managing the negative impacts of firms' activities on the environmental is as important as managing the business itself. This will enable firms minimise their environmental costs and liabilities and increase the potential benefits to the firm. In view of these, it is recommended that firms implement environmental management initiatives, and all relevant stakeholders such as government and professional accounting bodies should be actively involved in promoting environmental related practices in order to bring to the fur the hidden potentials and benefits that accrue therefrom. Future studies may inclusion more predictive variables which may likely make the model have higher predictive value and thus reveal more determinants of SED and market value. 


\section{REFERENCES}

Abbott, W., \& Monsen, R.J. (1979). On the measurement of corporate social responsibility: Selfreported disclosures as a method of measuring corporate social involvement. Academy of Management Journal, 22(3), 501-515.

Adeyemi, S.B., \& Ayanlola, O.S. (2015). Regulatory perspective for deepening CSR disclosure practice in Nigeria. African Journal of Business management, 9(6), 270-287.

Akbas, H.E. (2014). Company characteristics and environmental disclosure: An empirical investigation on companies listed on Borsa Istanbul. The Journal of Accounting and Finance, 2(2), 145-164.

Akinlo, 0.0., \& Iredele, 0.0. (2014). Corporate environmental disclosures and market value of quoted companies in Nigeria. Business and Management Review, 5(3), 171-184 .

Andrikopoulos, A., \& Kriklani, N. (2012). Environmental disclosures and financial characteristics of the firm: A study of Denmark. Corporate Social Responsibility and Environmental Management, 20.

Appah, E. (2011). Social accounting disclosures in annual reports of Nigerian companies. Asian Journal of business Management, 3(3), 145-151.

Asteriou, D., \& Hall, S.G. (2007). Applied Econometrics. New York: Palgrave Macmillan.

Barth, M.E., Cahan, S.F., Chen, L., \& Venter, E.R. (2016). The economic consequences associated with integrated report quality: early evidence from a mandatory setting. Working paper. https://dx.doi.org/10.2139/ssrn.2699409.

Barney, B.J. (1991). The prescriptive limits and potential for applying strategic management theory. Managerial and Decision Economics, in press.

Baye, M.R. (2006). Managerial Economics \& Business Strategy (5th ed.). New Delhi: McGraw Hill.

Cassidy, D. (2003). Maximizing shareholder value: The risks to employees, customers and community. Corporate Governance, 3, 32-37.

Carnevale, C., Mazzuca, M., \& Venturini, S. (2011). Corporate social reporting in European banks: the effect on firms' market value. Corporate Social Responsibility and Environmental management, 19(3), 159-177.

Chami, R., Cosmano, T.F., \& Fullenkamp, C. (2002). Managing ethical risks: How investing in ethics adds value. Journal of Banking and Finance, 26, 1697-1718.

Chan, N. (1996). A stakeholder theory perspective to corporate environmental disclosures. Journal of Contemporary Business, 3(3), 29-33.

Dasgupta, S., Laplante, B., \& Mamingi, N. (1998). Understanding firm's environmental performance. Environmental economics and policy study, 9(2), 67-79.

Deegan, C. (2002). The legitimising effect of social and environmental disclosures: A theoretical foundation. Accounting, Auditing and Accountability Journal, 15(3), 282-311.

Deegan, C.M. (2007). Financial Accounting Theory (2nd ed.). Australia: McGraw-Hill. 
Duke, J., \& Kankpang, K. (2013). Implications of corporate social responsibility for performance of Nigerian firms. Advances in Management and Applied Economics, 3(5), $1-5$.

Enahoro, A. (2009). Corporate characteristics and sustainability reporting environmental agency moderating effects. IOSR Journal of Humanities and Social Science, 8(10) 19-30.

Etzioni, A. (1988). The moral dimensions: Toward a new economics. New York: Macmillan.

Field, A (2005). Discovering Statistics using SPSS. London: SAGE Publications.

Funk, K. (2003). Sustainability and performance. MIT Sloan Management Review, $44(2), 65-70$.

Gray, R.H., \& Bebbington, J. (2001). Accounting for the Environment (2nd ed.). London: SAGE Publications. https://dx.doi.org/10.4135/9781446220849.

Gray, R., Kouhy, R., \& Lavers, S. (1995). Corporate social and environmental reporting: A review of the literature and a longitudinal study of UK disclosure. Accounting, $A u$ diting and Accountability Journal, 8(2), 47-77.

Hart, 0. (1995). Corporate governance: some theory and implications. The Economic Journal, 195(430), 678-689.

Hindley, T., \& Buys, P.W. (2012). Integrated reporting compliance with the Global Reporting Initiative framework: An analysis of the South African mining industry. International Business \& Economics Research Journal, 11(11), 1249-1260.

Hossain, M., \& Hammami, H. (2009). Voluntary disclosure in the annual reports of an emerging country: The case of Qatar. Advances in Accounting, 25(2), 255-265.

Hyang, M.C., Wonsik, S., \& Sang, K.M. (2012) Foreign board membership and firm value in Korea. Management Decision, 50(2), 207-233.

Jaggi, B., \& Freedman, M.B. (1992). An Examination of the Impact of Pollution Performance on Economic and Market Performance: Pulp and Paper Firms. Journal of Business Finance \& Accounting, 19(5), 697-713.

Kamangue, C.W., \& Ngugi, J.K. (2013). The influence of board attributes on firm value: A case study of the unit trusts in Kenya. European Journal of Management Sciences and Economics, 1(2), 58-69.

Konar, S., \& Cohen, M.A. (2001). Does the market value environmental performance? The Review of Economics and Statistics, 83(2), 281-289.

KPMG (2011). KPMG International Survey of Corporate Responsibility Reporting, http://www.kpmg.com (accessed: 01.10.2012).

KPMG (2015). International survey of corporate responsibility reporting. KPMG Global sustainability services, Amsterdam.

Laabs, J. (2012). What is your business worth? The business center. Extracted from http://www.businesssalecenter.com/new.page3 (accessed: 01.06.2013).

Lars, H., Henrik, N., \& Siv, N. (2005). Value relevance of environmental performance. European Accounting Review, 14(1), 41-61.

Li, Y., Gong, M., Zhang, X., \& Koh, L. (2017). The impact of environment, social and governance disclosure on firm value: the role of CEO power. The British Accounting Review. https://dx.doi.org/10.1016/j.bar.2017.09.007. 
Lo, S., \& Sheu, H. (2007). Is Corporate Sustainability a Value-Increasing Strategy for Business? Corporate Governance, 15(2), 345-358.

Malik, M. (2014). Value-enhancing capabilities of CSR: A brief review of contemporary literature. Journal of Business Ethics, 1, 1-48.

Mathuva, D.M., Barako, D.G., \& Wachira, M.M. (2017). The Economic Consequences of Environmental, Social and Governance Disclosures by Firms Quoted on the Nairobi Securities Exchange. African Accounting Finance Journal, 1(1), 5-28.

McConnell, J., \& Servaes, H. (1990). Additional evidence on equity ownership and corporate value. Journal of Financial Economics, 27(2), 595-612.

Michaely, R., \& Roberts, M. (2007). Dividend smoothing, agency costs, and information asymmetry: lessons from determinants of firm value within the banking industry. Working paper Cornell University. New York: Ithaca.

Modigliani, F., \& Miller, M.H. (1958). The cost of capital, corporation taxes and the theory of investment. American Economic Review, 58, 261-297.

Mohammed, D.U., \& Abubakar, Z.A. (2014). The nexus between corporate social responsibility and financial performance in Nigeria Research. Journal of Finance and Accounting, 5(10), 131-137.

Morck, F., Shleifer., G., \& Vashny, C. (1988). Management Ownership and Market Valuation: An Empirical Analysis. Journal of Financial Economics, 20(1-2), 293-315.

Natali, S., Lars, G., Hasseli, \& Henrik, N. (2009). The value relevance of environmental and social performance: evidence from Swedish 300 companies. Sustainable Investment and Corporate Governance Working Papers from Sustainable Investment Research Platform, 2009/4.

Ngwakwe, C.C. (2009). Environmental Responsibility and firm performance: Evidence from Nigeria. International Journal of Human \& Social Science, 4(6), 384-391.

Oba, V. (2012). The impact of corporate social responsibility on market value of quoted conglomerates in Nigeria. ICAN Journal of Accounting and Finance, 1(3) 64-70.

Oba, V., Fodio, M., \& Soje, B. (2012). The value relevance of environmental responsibility information disclosure in Nigeria. ACTA Universities Danubius, 8(6), 100-113.

O’Dwyer, B. (2011). Managerial perceptions of corporate social disclosure: an Irish story. Accounting, Auditing and Accountability Journal, 15(3), 406-436.

Owen, D. (2008) Chronicles of Wasted Time? A Personal Reflection on the Current State of, and Future Prospects for Social and Environmental Accounting Research. Accounting, Auditing and Accountability Journal, 21(2), 240-267.

Panwar, R., \& Hansen, E.N. (2009) A Process for Identifying Social and Environmental Issues: A Case of the US Forest Products Manufacturing Industry. Journal of Public Affairs, 9(4), 323-336.

Plumlee, M., Brown, D., Hayes, R., \& Marshall, S. (2010) Voluntary environmental disclosure quality and firm value: further evidence. Journal of Accounting and Public Policy, 34(4), 336-361.

Qui, Y., Shaukat, A., \& Tharyan, R. (2016). Environmental and social disclosure: Link with corporate financial performance. The British Accounting Review, 48, 102-116. 
Rockness, J, Schlachter, P., \& Rockness, H. (1986). Hazardous waste disposal, corporate disclosure and financial performance. Journal of Business Finance and Accounting, $12,339-354$.

Schadewitz, H., \& Niskala, M. (2010). Communication via responsibility reporting and effects on firm value in Finland. Corporate Responsibility and Environmental Management, 17(2), 83-93.

Shil, N.C., \& Paramanik, A.K. (2009). A look into the disclosure improvements for CSR reporting in Bangladesh. Malaysia Accounting Review, 8(2), 67-83.

Shin-Ping, L., \& Hui-Ju, C. (2011). Corporate governance and firm value as determinants of Chief Executive Officers compensation in Taiwan: 2SLS for panel data model. Management Research Review, 341(3), 252-265.

Smith, C.W., \& Watts, R.L. (1992). Investment opportunity set and corporate financing, dividend and compensation policy. Journal of Financial Economics, 32(3), 263-292.

Taufik, R., Widyastuti, T., \& Yam, J.H. (2017). Impact of good corporate governance, intellectual capital and firm policy on firm performance (empirical study of Indonesian commercial banks listed on Indonesian Stock Exchange (IDX) on 2010-2015). International Journal of Advanced Scientific Research and Development, 4(3), 11-30.

Turnbull, S. (1997). Corporate governance: Its scope, concerns and theories. Corporate governance, 5(4), 180-205.

Uwuigbe, U., Uwuigbe, O.R., \& Ajayi, O.A. (2011). Corporate Social Responsibility Disclosures by Environmentally Visible Corporations: A Study of Selected Firms in Nigeria. European Journal of Business and Management, 3(9), 9-11.

Wahba, H. (2008). Does the market value corporate environmental responsibility? An empirical examination. Corporate Social Responsibility and Environmental Management, 15(2), 89-99.

Walley, N., \& Whitehead, B. (1994). It's not easy to be green. Harvard Business Review, $3,46-52$.

Wang, K., Sewon, O., \& Claiborne, C. (2008). Determinants and consequences of voluntary disclosure in an emerging market: evidence from China. Journal of International Account Audit Tax, 17(4), 14-30.

Webb, L.H., Cohen, J.R., Nath, L., \& Wood, D. (2009). The supply of corporate social responsibility disclosures among U.S. firms. Journal of Business Ethics, 84, 497-527.

Williams, S. (1999). Relationship between intellectual capital performance and reporting related. Journal of Intellectual Capital, 2(3), 192-203. 
Appendix 1. Variable definitions

\begin{tabular}{|c|c|c|c|}
\hline Variable & Measure & Definition & Sources \\
\hline Tobin's Q & Firm Value & $\begin{array}{l}\text { Market value of equity plus book value } \\
\text { of total liabilities divided by total assets. }\end{array}$ & Annual Report \\
\hline CSED & $\begin{array}{l}\text { Corporate Social } \\
\text { Environmental } \\
\text { Discosure }\end{array}$ & $\begin{array}{l}\text { A score of (1) if the item is reported and (0) } \\
\text { if not reported }\end{array}$ & Annual Reports \\
\hline Size & Firm Size & Natural log of total asset & Annual Report \\
\hline ROE & $\begin{array}{l}\text { Financial perfor- } \\
\text { mance }\end{array}$ & $\begin{array}{l}\text { Income (after tax) before extraordinary } \\
\text { item divided by total assets }\end{array}$ & Annual Report \\
\hline BS & Board Size & Number of persons on the board & Annual Report \\
\hline LEV & Leverage & $\frac{\text { Total Debt }}{\text { Total Equity }}$ & Annual Report \\
\hline AffI & Affiliation & Foreign company (1), Local (0) & Annual Report \\
\hline Ind & Industry & $\begin{array}{l}\text { Environmental sensitive ind (1), } \\
\text { non-sensitive industry (0) }\end{array}$ & Annual Report \\
\hline
\end{tabular}

S o u r c e : Annual Reports of companies. 